
Journal of NELTA Gandaki (JoNG)
(A peer reviewed Open Access Research Journal)
ISSN: 2676-1041 [Print]
E-ISSN 2822-1559 [Online]
Vol. IV Issue (1-2) November, 2021, pp. 98-108
eJournal site: www.nelta.org.np/page/gandaki

\title{
English Teachers' Perceptions on Inquiry Based Teaching
}

Prem Raj Pokhrel

\section{Article History:}

Submitted 22 June, 2021

Reviewed 30 September 2021

Accepted 30 October 2021

Prem Raj Pokhrel

Email:

pokhrelpremraj61@gmail.com

Article DOI:

https://doi.org/10.3126/jong.v4i1-2.42647

Copyright 2021 Author/s and Nepal English Language Teachers'

Association, Gandaki Province

This work is licensed under a

Commercial

4.0 International License

Publisher

Nepal English Language Teachers'

Association Gandaki Province, Pokhara, Nepal

Email: neltagandaki2018@gmail.com

URL.:www.nelta.org.np/page/gandaki
Corresponding Author:

Copyright information:

Creative Commons Attribution- Non

\section{(c) $\$$}

\section{Abstract}

This study explores the perceptions of secondary level English teachers on inquiry based teaching. I used phenomenological approach for this study and semi-structured interview was used for data collection which enabled me in capturing the perceptions of purposefully selected participants. The participants were four secondary level English teachers of Rupandehi district. Moreover, this study was based on socio-constructivism theory of Vygotsky. The data were analyzed using descriptive analysis approach. The findings of this study revealed that secondary level English teachers had good perceptions towards using inquiry-based teaching as it enhanced students' classroom engagement and fostered an effective and meaningful learning experience. The study pointed out a number of opportunities in using inquiry based teaching such as active participation of students, developing discovery skills, the development of critical ability, creativity, problem solving ability, reasoning skills, learners' autonomy, etc.The findings also indicated that problem in handling technology, lack of motivation and transformation, assessment issues were the challenges while implementing inquiry based instruction in the classroom. The study is expected to have a great significance in improving the $21^{\text {st }}$ century language pedagogy using inquiry based tasks or problems.

Keywords: inquiry based teaching, critical thinking, creativity, learners' autonomy, assessment

\section{Introduction}

The development of language teaching methodology has undergone several stages over the last century. Language teaching involves not only what to teach but also how to teach and in ELT several 
approaches are in practice and one of the recent approaches that engage learners actively in a knowledgebuilding process through the generation of answerable questions is inquiry based teaching (Harada \& Yoshina, 2004). It means generation of answerable questions in the classroom plays a vital role. Similarly, Rejeki (2017) argues that students doing inquiry learning tend to look, act, and think differently from students doing traditional learning. Additionally, the U. S. National Research Council (2002) describes inquiry in terms of its importance in investigating scientific questions and developing strategies that will support them as scientific learners. Real inquiry is for seeking truth, information, knowledge or understanding and is used in all facets and phases of life. Similarly, Pedaste and Sarapuu (2006) state that inquiry based learning is an approach in which learners solve problems by using their inquiry skills. In fact, the quality questions raised in inquiry based approach lead to discussions, interactions and collaborations between teachers and students that compel the students to remain active in the classroom.

I still remember my school English teachers who taught me English using question answer technique but they became more active themselves rather than activating their students. They gave questions, rules and readymade answer from the textbook which we were supposed to memorize within a given time. Though this kind of exposure provided us a kind of mental training, it couldn't make us read, re-read, think and reflect. I have experienced learning in a more different way now than I was taught during my school days.

As I attended some regional and national training programs, conferences, and workshop, I realized that teaching learning activities should be shifted from teacher centered pedagogy to student centered pedagogy. Concerning the school level English curriculum of Nepal, the Ministry of Education has introduced communicative language teaching (CLT) in textbooks since 1995 and has also emphasized learner-centeredness (Tin, 2014). English is taught today under democratic conditions, not under the galling restraints of regimentation' (Rai, 2003 cited in Tin, 2014). In this context of making students active to achieve both linguistic and communicative competence, inquiry based teaching fits the situation. This paper tries to find out the perceptions of secondary level English teachers on inquiry based teaching. To achieve answer to this objective, I seek to answer the questions

What do secondary level English language teachers understand by inquiry teaching?

1. What are the opportunities and challenges of using inquiry based teaching in secondary level English Classrooms?

\section{Review of Literature}

This section explores the concepts of inquiry based teaching in language pedagogy, relevant literature related to the study and the theory of socio-constructivism that link inquiry based teaching and learning to the construction of knowledge and skills.

\section{Inquiry Based Teaching in Language Pedagogy}

The fundamental concept in inquiry based teaching regards to a process of personal discovery by the learners. Learners or the student inquirers are guided to inquire or generate relevant questions and to come up with the appropriate answers through critical thinking (Ismail \& Alias, 2006). There is much confusion 
among teachers over the meaning of the term 'inquiry' Wheeler (2000) stated "inquiry has been referred to as elastic term that can be stretched and twisted to fit people's differing world views" (p.14). In inquiry based teaching, students become active as they undertake real problems, issues, and questions, consult with experts and work collaboratively. Perkins (2009) argued that students should be given opportunities to "play the whole game" where they can experience junior versions of how knowledge is created and communicated within specific disciplines. In inquiry based learning, students are invited to collaborate in order to create new knowledge, think critically and creatively, and to make discoveries through, reflection, exploration, experimentation, and trial and error" (Alberta Education, 2010). Similarly, Lee (2014) focused that instead of learning passively; inquiry stimulates students to actively engage in cognitive and discovery learning activities. Most importantly, it supports the development of learner's cognitive and meta-cognitive strategies.

In inquiry based teaching, students develop their own community where they ask questions and develop solution as Fauziati (2014) pointed out that students ask questions and find the answers by themselves with some kind of help from the teacher, technology, and their learning community. The students construct the knowledge by combining what they have known and what they want to know (cited in Rejeki, 2013). Inquiry based learning as a learner-centered approach that requires students to bear primary responsibility in knowledge construction and application, timely and appropriate instructional scaffolding interventions by the educator and/or the digital learning environment are of paramount importance (Chu et al., 2017). In fact, , students make meaningful and thoughtful connections to the world around them by asking questions, creating solutions and involving them in different project based learning in inquiry based teaching.

In inquiry based teaching, learners independently or with little guidance of their teacher undertake the process of investigation and final presentations of their conclusions and reflections (Pinker, 1996). Similarly, Sadler (1989) illustrated that when using the type of open-inquiry, the teacher stimulates students to use different methods to construct knowledge either individually or in groups. Thus, the context of inquiry is not just the educators are concerned with but it also concerned with the cultural and linguistic world. Sadler (1989) also highlighted that inquiry-based teaching doesn't only teach students, but also they teach how to impact the world. This idea leads us to learn the fact that students really do the tasks and feel that they have learnt something in inquiry based teaching.

\section{Constructivism and Inquiry-Based Teaching}

Research shows that social constructivism can lead to effective teaching methods because it allows students to work in collaboration to construct knowledge and understand it through a critical lens, with the support of peers (Powell \& Kalina, 2009). Social constructivist theorists John Dewey, Vygotsky, and Paulo Freire played a vital role in the development of inquiry (Powell \& Kalina, 2009). John Dewey, an educational philosopher and social constructivist theorist, presented a progressive approach to education in the 20th century. In this view, he strongly opposed rote learning because it does not allow students to develop critical skills or encourage curiosity. In order to prepare students for success, Dewey suggested that students actively make meaning of knowledge through social interaction with others to experience, 
understand and reflect on the process of learning (Dewey, 1938). He argued learning is a social process whereby students learn all the time in their environment without external control by authority (Dewey, 1938).This idea focuses on the role of students as active participants in the process of acquiring knowledge, while the teacher acts as a facilitator. Paulo Freire (1970) argued against the oppressed traditional teaching methods, which he described as the banking concept of education. He suggested that educators reject this model and replace it with problem posing education, which is very much reflective of the inquiry-based learning model (cited in Durakoglu, 2013). In this inquiry model, both the teachers and students have equal power, the teacher does not have "absolute knowledge" and they both engage in dialogue to construct knowledge together (Durakoglu, 2013). Vygotsky ( 1978) further expanded this thinking by suggesting that effective learning in the classroom occurs in a socio-cultural context, through social interaction and cooperation with peers and teachers (Cited in Powell \& Kalina, 2009). Vygotsky further emphasized the role of zone of proximal development, the more knowledgeable other and language development, which is a cultural artifact to discuss its significance in the classroom. He suggested learning in this zone occurs voluntarily. In inquiry based teaching, an experienced teacher or with qualified peers, through a dialogic process, students' ability to comprehend knowledge increases (Lantolf\& Appel, 1994). This concept clearly tells us that in inquiry based teaching students construct knowledge with the help of interactions and collaborations. They don't receive the knowledge.

\section{Methodology}

For the purpose of this study, I followed phenomenological design to derive meaning from the reality. I selected four different schools (two community and two institutional schools) from Butwal submetropolitan city of Rupandehi district purposively. Four secondary level English teachers who practice inquiry based teaching were selected purposively as participants for the study. Semi-structured interview which is the most common type of interview in qualitative social research was used as data collection technique to collect data First, I informed them and took permission and fixed the time for interview. Then I took semi structured interview to withdraw information. The interview was recorded in the zoom .After the collection of data through zoom interview, data were transcribed, classified and described into different categories under different themes.

\section{Results and Discussion}

Analysis of the data is based on phenomenological approach. Analysis of the data revealed three different categories: perception of teachers on inquiry based teaching, their perception about the opportunities of using inquiry based teaching over teacher centered approaches and finally their perceptions on challenges they have faced while implementing inquiry based teaching in the classroom.

\section{Teachers' Perception on Inquiry Based Teaching}

English teachers were asked to describe and explain the perceptions of inquiry based teaching with the intention to learn the meaning they attached to it. Through analysis of the interview, I tried to learn how the participants perceive inquiry based teaching from their perspectives. The respondents were found to have good understanding or perception on inquiry based teaching. Regarding the perception on use of 
inquiry based teaching in a language classroom participant 'A' explained, inquiry based teaching activates students in the class as they involve solving tasks, problems or questions with inquiry mindset exploring the content and sharing their ideas. This idea strongly suggests that inquiry teaching activates the students in doing tasks and solving problems in the classroom as Chu et al. (2017) views that inquiry based is related to problem-and project-based learning, in which learners adopt an inquiry mindset in addressing and completing projects with a relatively open-ended set of answers as a short- term classroom activity or long-term assignment.

Similarly, participant B responded inquiry pedagogy makes students involved in asking, investigating, creating, discussing and reflecting where they seek for teachers' support. This response mainly highlights the positive perception of the participant as it is a student centered approach that activates students in the class making them engage in different tasks, discussions and interactions. This participant reveals the perception of inquiry as explained by Bruce and Bishop (2002) who suggest that an inquiry process must consist of five elements: ask, investigate, create, discuss, and reflect. This perception reveals that inquiry based teaching begins with questions and ends with reflections.

A similar perception of inquiry can be inferred from the response expressed by participant $\mathrm{C}$ who explained inquiry based teaching as an approach that emphasizes problem based learning and starts by questioning and discover a proper answer of a question usually in groups or community. This perception of inquiry reveals the meaning that inquiry based teaching in general approach that includes problem based, task based or project based learning. It is more clearly explained by Chu et al.(2017) as they state inquiry approach is related to problem-and project-based learning, in which learners adopt an inquiry mindset in addressing epistemic issues or in developing and completing projects with a relatively open-ended set of answers. Participant D explained inquiry based teaching focuses on questioning, discussing over those questions, collecting information from different, solving the questions and reflecting. This view intends to focus on the fact that inquiry approach is different from others as it primarily focuses on generating questions and arriving at the solutions through discussions and sharing information. This view is similar to what state "students focus on answering compelling questions, or getting a better understanding of the questions they have raised. Instructors support this process, acting as resource people and animators and introducing intellectual and academic skills as they are needed (Justice, et al., 2009, p.843). This view mentions that teachers are really resource persons and facilitators in inquiry based pedagogy.

When students are involved in questioning and solving those questions through discussions, they construct knowledge as Brooks and Brooks (1999) state "as long as there were people asking each other questions, we have had constructivist classrooms. Constructivism, the study of learning, is about how we all make sense of our world, and that really hasn't changed" (p.76). Much of constructed knowledge is filtered through social negotiation or distributed cognition (Brown et.al, 1995). The analysis of these different views of the participants on perception of teachers on inquiry based teaching clearly reveal that inquiry based teaching is the student centered pedagogy which focuses on the process of making students active through the generation of answerable questions with collaboration, discussions and discovery of information. 


\section{Why Inquiry Based Teaching?}

The question of "Why inquiry based teaching?" is important, as the approach is supported by its effectiveness. Some believe that IBT is the most effective learning strategy because it displays ideas in an organic manner (Bybee, 2002, \& Crawford, 2007). Likewise Bateman (1990) states that inquiry based teaching is more than a model for learning. It is a step towards life that encompasses student's engagement to create strategic solutions for realistic problems they face and search for. Similarly,. The participants expressed the similar view for question "Why do you prefer using inquiry based teaching?" Participant A responded 'I use inquiry based teaching as it enhances learners' autonomy, fosters students' curiosity and critical thinking power and it creates love of learning. This idea of participant A indicates that inquiry based teaching is used for developing independency, developing creativity, critical thinking and curiosity of the students. This idea of the participant is very much similar to what is expressed in Ontario (2006) "students are encouraged from a very early age to develop their ability to ask questions, and to explore a variety of possible answers. The ability to locate, question and validate information allows a student to become an independent, lifelong learner"(p.29).Similarly, participant B expressed a similar view as he responded I prefer to use inquiry pedagogy in the classroom as it enables reflection, self-learning, creativity and critical power of the students. This view of the participant is similar to the view that inquiry based learning can be a benefit to both students and teachers alike as it allows them to be more reflective and make interpretations of their learning (Olagoke \& Mobolaji, 2014). This concept leads us to generalize the idea that there is discussion, interaction, discovery and reflection in inquiry based classroom.

Regarding the rationale behind using inquiry based teaching, participant $\mathrm{C}$ replied I use inquiry based teaching to create enjoyment in learning, provide sense of independency, and to problematize learning process where students derive meaning through sharing group culture. This participant focuses that using inquiry-based teaching with students can help them create enjoyments in learning and making them more positive and more independent. Moreover, inquiry-based teaching provides opportunities for students to develop skills they need all their lives and to cope with problems that may not have clear solution. This perception of the participant clearly supports the idea expressed by Kong and Song (2014) who found inquiry based teaching improved in their domain knowledge learning and inquiry skills, especially in questioning and explanation developed skills needed to assess their own work, monitor progress and enjoyed taking control of their own learning. Likewise, Chu (2009) also found that inquiry based instruction developed high feeling of positive enjoyment, and motivation because they were able to control their learning in the learning process. It is revealed that inquiry based teaching results enjoyment and motivation in learning.

The perception of the participants regarding the benefits of inquiry based teaching is also emphasized by socio constructivism theory as the theory emphasizes on social interactions. In an inquiry classroom students are able to participate in a dialogic process whereby they are able to reflect on their experiences and voice their opinions on ideas and critical issues in the world (Walker, 2013; Wadden, 2003). When a safe collaborative community is created within the classroom, students are more engaged and feel comfortable building on their peer's opinions, they use this platform of trust to voice their own opinions (Walker, 2013; 
Wadden, 2003). Inquiry based teaching forces students to engage in solving the questions with the help of their own experiences and with the help of their teachers and peers.

\section{Challenges for Implementation}

Researchers have shown that students have difficulties conducting systematic scientific investigations. Data gathering, analysis, interpretation, and communication are all challenging tasks that are made more difficult by the need for content-area knowledge (Kraijcik et al., 1998). On the basis of the information obtained from the participants, I have categorized challenges into three sub- themes; technology related, assessment related and motivation and transformation related challenges.

\section{Transformation and Motivation Related Challenges}

Research studies have explored that motivation is a primary factor affecting inquiry based instruction. Edelson and his colleagues (1999) addressed that motivation is the first challenge in IBL. In order to motivate learners, they argue that teachers should include topics of interest that will foster a better focus in their investigations (Edelson et al., 1999). Regarding my question to the participants about the challenges they faced in inquiry based instruction, participant A stated "Transforming the students from the teacher centred instruction to inquiry based instruction and motivating them to the process of investigation, analysis and interpretation is a big challenge. This opinion of the participant clearly shows that motivating and transforming the students in the process of inquiry is the serious challenge for the teachers. This idea is strongly supported by Trautmann, MaKinster, and Avery (2004) who explained that lack of resources and educational support concerned with the issue of motivation for some teachers to engage students in this form of learning.

Regarding this issue, participant B mentioned, students find inquiry process especially generating open ended questions more difficult and don't seem to be more motivated. They want everything from teachers like in teacher centered approach. This perception of the participant clearly shows that students in a language classroom still want readymade materials and questions from the teachers and pushing them towards the process of generating questions is a serious threat for the teacher. When students are not sufficiently motivated or are not motivated by legitimate interest, they either fail to participate in inquiry activities or they participate in them in a disengaged manner that does not support learning. In their findings, Puk and Haines (1998) found that students are not well motivated as many teachers do not implement inquiry because they do not know how to teach it. They claimed teachers are not trained well, and do not understand the importance of this form of instruction.

\section{Assessment Related Challenges}

The aim of this assessment is not to assess but to help the students in identifying their problems and suggesting solution. Related to IBLL, the teacher can conduct formative assessment while teaching and learning activities occur. Heritage (2010) argues that the given feedbacks in formative assessment is most effective when it is focused on the task and provides the students with suggestions, hints, or cues, rather than offered in the form of praise or comments about the performance ( cited in Rejeki,2013)

One of the greatest concerns for teachers in implementing inquiry-based instruction is the fear of 
losing control, control of instruction, control of students, and control of the class. All these activities go out of control if assessment techniques are not authentic. Regarding the question related to challenges, participant $\mathrm{C}$ responded: Assessing the students has been a great issue in a language classroom at the present time and this has become more serious issue in student centered pedagogy like in inquiry based instruction. This participant raised the problem of assessing students in inquiry based instruction. He also indicated that evaluating students' knowledge is another challenge as we need to follow continuous or formative assessment rather than summative one.

Assessment in an inquiry classroom differs from that of a traditional classroom in that it is based on the child's growth throughout the learning process as opposed to perceived outcomes (Wadden, 2003). Regarding the issue of assessment participant $D$ replied students prefer summative evaluation for assessing the performance but in inquiry based assessment authentic continuous assessment is needed for true evaluation. This participant expressed the idea that teachers try to evaluate the performance through continuous formative assessment but students prefer traditional summative assessment which is another serious challenge for teachers. Teachers are stepping back from using "formal testing" and placing more emphasis on using portfolio conferencing as a form of assessment that will hold students accountable for learning in inquiry classrooms (Wadden, 2003). In this regard, Dumont et al., (2010) identify three elements of assessment: performance assessment, evaluation tools and formative assessments each of which play a critical role in inquiry based learning to solve the problem.

\section{Technology Related Challenges}

It is widely believed that through the integration of technology into the curriculum, students can improve linguistic skills, and at the same time they can learn different perspectives on a topic, different cultural aspects, and develop social skills. Technology is radically transforming teaching and learning, as inquiry-based digital information resources and creative tools are made available to learners, schools, and educators (Chu et al., 2017).Regarding the question asked about challenges, participant A replied "All schools don't have well equipped classes for inquiry activities to take place. All teachers and students don't have access to technological resources. Some teachers are still unaware of using technology in inquiry based teaching.This participant mainly talked about the problem of the availability of the technological tools and the problem of teachers' efficiency in using the technological resources. In this context, Edelson et al. (1999) state that the technologies and activities of inquiry-based learning must fit within the practical constraints of the learning environment, such as the restrictions imposed by available resources and fixed schedules.

Regarding this question related to the challenges of implementing inquiry based teaching, participant B explained, Most of the teachers are unable to handle technology related inquiry activities. Investigation, analysis and interpretation process of inquiry activity sometimes have to be supported by technological part. This view of the participant also supports the idea that handling technology is one of the serious problems of implementing inquiry based instruction. This view is well supported by Crippen, and Archambault, (2012) as they emphasize that to take advantage of these new technologies to benefit student learning, 
teachers need to become aware of their existence, learn how to use them, and become comfortable with the methods by which they are implemented for both classroom and home use. It becomes quite clear now that like in other approaches, technology related problems also create difficulty in inquiry based pedagogy.

\section{Conclusion and Implications}

The findings of this study clearly indicate that teachers of secondary level had a good understanding or perception on inquiry based teaching as an approach that makes students active, motivates towards collaborating and cooperating, makes students autonomous, develops critical and creative ability. It was also perceived that inquiry-based teaching is a profitable learning model to inductively teach students the skills of 21 st century by focusing on researching and being autonomous learners. Despite having some challenges for implementation, inquiry based instruction can be used in the classroom successfully with the help of technology, awareness on training teachers, and with alternative assessment system in evaluation.

The findings of this study are believed to have some practical implications. First, this study will have a profound impact on my research practice, in that I now feel more committed to continue researching strategies I can effectively use to improve my own teaching practice in using inquiry-based teaching and learning. Secondly, assessment system in inquiry based teaching could be based on continuous and formative assessment and it is for more for assistance rather than for assessment. Third, scaffolding support could be provided to students in developing driving questions and students should go through an information-seeking process. Fourth, implication could be that both students and teachers should be familiar with handling modern technology for effective inquiry based teaching and learning. Finally, as this qualitative study mainly explored the secondary level English teachers' perceptions of inquiry based instruction; further research can take place in different levels following quantitative or mixed methods or any other paradigms in different areas of inquiry for enriching our understanding in the pedagogy.

\section{References}

Alberta Education. (2010). Inspiring education: A dialogue with Albertans. Alberta Education.

Bateman,W. (1990). Open to question: The art of teaching and learning by inquiry: Jossey-Bass.

Brooks, M. G., \& Brooks, J. G. (1999). The courage to be constructivist. Educational Leadership, 57(3). https://eric.ed.gov/

Brown, AL, Ash,D., Rutherford, M., Nakagawa, K., Gordon, A., \& Campione, J .C. (1995). In G. Salomon (Ed.), Distributed cognitions. Distributed expertise in the classroom. Cambridge University Press.

Bruce, B., \& Bishop, A. (2002).Using the web to support inquiry based literacy development. Journal of Adolescent \& Adult Literacy, 45(8), 706-714.

Bybee, R. W. (2002). Scientific inquiry, student learning, and the science curriculum. Learning Science and the Science of Learning, 24(3) 25-35.

Chu, S.(2009). Inquiry project-based learning with a partnership of three types of teachers and the school librarian. Journal of the American Society for Information Science and Technology, 60(8) 16711686.

Chu,S.K.W., Reynolds, R. B.,Tavares, N.J.,Notari, M. \& Lee, C. W.Y. (2017). $21^{\text {st }}$ century skills 
development through inquiry based learning. Springer.

Crawford, B. A. (2007). Learning to teach science as inquiry in the rough and tumble of practice. Journal of Research in Science Teaching, 44(4), 613-642.

Crippen, K. J. \& Archambault, L. (2012): Scaffolded inquiry-based instruction with technology: A signature pedagogy for STEM education, Computers in the Schools,29(1-2), 157-173

Dewey, J. (1938). Experience and education. Macmillan.

Dumont, H., Istance, D., \& Benavides, F. (2010). The Nature of learning using research to inspire practice. 12https://www.oecd.org/education/ceri/50300814.pdf

Durakolu, A. (2013). Paulo Freire's perception of dialogue based education. International Journal on New Trends in Education and their Implications, 4(3) 1309-6249.

Edelson, D., Gordin, D., \& Pea, R. (1999). Addressing the challenges of inquiry-based learning through technology and curriculum design. Journal of the Learning Sciences, 8(3-4) 391-450.

Harada, V. H., \& Yoshina, J. M. (2004). Inquiry learning through librarian-teacher partnerships. Linworth Publishing.

Ismail, N.,\&Alias,S.E. (2006). Inquiry based learning: A new approach to classroom learning. English Language Journal, 2(1) 13-24. file:///C:/Users/user/Downloads/Inquiry_Based_Learning_A_New Approach to.pdf

Justice, C.,Rice, J., Ray, D., Hudspith, B.,\& Jenkins, H. (2009). Inquiry based learning in higher education: Adminstrator's perspectives on integrating inquiry pedagogy into the curriculum. Higher Education, 58(6), 841-855.

Kong, S. C., \& Song, Y. (2014).The impact of a principle-based pedagogical design on inquiry-based learning in a seamless learning environment in Hong Kong. Educational Technology \& Society, 17(2), $127-141$.

Krajcik, J.,Blumenfeld, P. C., Marx,R. W., Bass, K. M.,Fredericks, J.,\& Soloway, E. (1998). Inquiry in project-based science classrooms: Initial attempts by middle school students.The Journal of the Learning Sciences, 7(3) 13-350.

Lantolf, J. P. and Appel, G. (eds.) (1994). Vygotskian approaches to second language research. Ablex Publishing.

Lee,H.Y. (2014). Inquiry-based teaching in second and foreign language pedagogy. Journal of Language Teaching and Research, 5(6), 1236-1244.

National Research Council (2002). Inquiry and the national science education standards: a guide for teaching and learning: The National Academies Press.

Olagoke, A.M., \& Mobolaji, O. S. (2014). Inquiry-based learning approaches: The best practice for basic science teachers.International Journal of Current Research and Review, 6 (15), 15.

Ontario Ministry of Education. (2006). The Ontario curriculum grade 1-8: Language. Retrieved from

Pedaste, M., \& Sarapuu, T. (2006). Developing an effective support system for inquiry learning in a webbased environment. Journal of Computer Assisted Learning, 22(1), 47-62.

Perkins, D. (2009). Making learning whole: How seven principles of teaching can transform education. 
Jossey-Bass.

Pinker, S. (1996). Language is a human instinct. In J. Brickman (Ed.), The third culture. Simon.

Powell, K. C. \& Kalina, C. J. (2009).Cognitive and social constructivism: developing tools for an effective classroom. Education, 130(2) 241-250.

Puk. T., \& Haines, J. (1998). Curriculum implementation in Ontario: Espoused and de facto aspirations for inquiry, McGill Journal of Education, 33(2), 189-206.

Rejeki, S. (2017). Inquiry based language learning (IBLL). Theoretical and practical views in English classroom. English Franca,1(02) 135-148.

Sadler, D. R. (1989). Formative assessment and the design of instructional systems. Instructional Sscience, $18(2)$ 119-144.

Tin, T.B.(2014). A look into the local pedagogy of an English language classroom in Nepal. Language Teaching Research. 18(3) 397-417.

Trautmann, C., MaKinster, J., \& Avery., L. (2004). What makes inquiry so hard? (And why is it worth it?). National Association for Research in the Science Teaching, 1-17.

Wadden, S. (2003). Inquiring minds Inquiry-based learning in primary classrooms. An unpublished Master's thesis in Mount Saint Vincent University.

Walker, C. (2013). Examining role diversification through dialog from small-group interactions during unit activities within inquiry-based teaching and learning classrooms [An unpublished doctoral dissertation] McGill University.

Wheeler, G. F. (2000). The three faces of inquiry. In J. Minstrell \& E. H. van Zee (Eds.), Inquiring into inquiry learning and teaching in science. National academic press.

Prem Raj Pokhrel is a lecturer of Tribhuvan University and has been teaching English at Butwal Multiple Campus for 16 years. He has published some national and international articles and has presented in different webinars. At present, he is a member of research committee at English language Education department of Butwal Multiple campus. His areas of interest include English language teaching methodology, English language teacher development, critical discourse analysis etc. Currently he is pursuing M.Phil.at Kathmandu University and he is a life member of NELTA. 